\title{
Right Hippocampal Abnormality on Diffusion-weighted MRI in Transient Global Amnesia: Case Report
}

\author{
Geçici Global Amnezi Olgusunda Difüzyon Ağırlıklı MRG'de Sağ Hipokampal Lezyon: \\ Olgu Sunumu
}

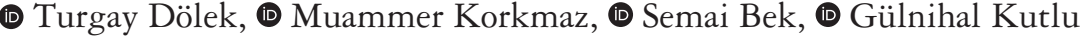 \\ Mugla Sitki Kocman University, Department of Neurology, Mugla, Turkey
}

\begin{abstract}

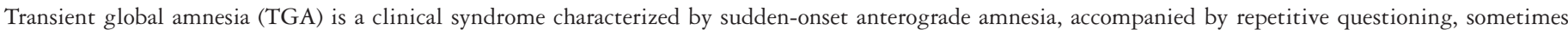

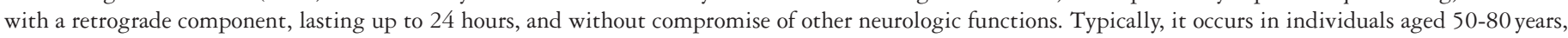

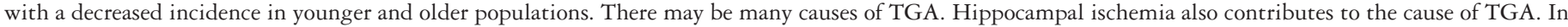

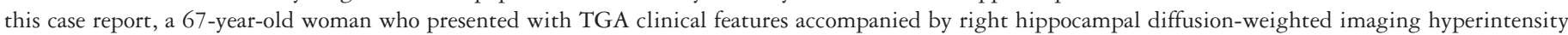
is presented.
\end{abstract}

Keywords: Transient global amnesia, diffusion-weighted MRI, hippocampus, infarct

Öz

Geçici global amnezi (GGA); tekrarlayan soru sormanın eşlik ettiği, bazen retrograd bileşeni olan, başka nörolojik fonksiyon kaybının olmadığı ve 24 saate kadar sürebilen ani başlangıçlı anterograd amnezi ile karakterize olan bir klinik sendromdur. Genellikle 50-80 yaşları arasında ortaya çıkar ve insidansı bu yaş aralığı dışındaki bireylerde daha düşüktür. GGA'nın birçok nedeni olabilir. Hipokampal iskemi de bir neden olarak GGA'ya katkıda bulunabilir. Bu olgu sunumunda, GGA kliniği ile prezente olan ve difüzyon ağırlıklı görüntülemede sağ hipokampal hiperintensite bulunan 67 yaşındaki bir kadın hasta sunulmuştur.

Anahtar Kelimeler: Geçici global amnezi, difüzyon ă̆ırlıklı MRG, hipokampus, enfarkt

\section{Introduction}

Transient global amnesia (TGA) is a clinical condition characterized by sudden-onset anterograde and retrograde amnesia that resolves within 24 hours without other neurologic symptoms. The person cannot recall any recent visual or verbal information that happened, except for the last few minutes. Besides amnesia, attention and sudden recall processes are also disrupted. Patients are awake during the attack and do not show any other neurologic symptoms such as weakness or numbness. They usually ask the same questions repeatedly. TGA attacks begin suddenly and generally last 1-24 hours. Headache and nausea may be observed. Recurrence is rare. Migraine, physical exercise, emotional stress, sexual intercourse, psychologic disorders, cervical hyperextension, vertebral angiography, and jugular vein incompetency are among the triggering factors/responsible mechanisms $(1,2)$. In addition, hippocampal ischemia contributes to the onset of TGA; however, its mechanism remains obscure (3). TGA is a benign disorder of episodic memory with no impairment of general cognitive functions or other components of memory $(3,4)$. We present a case due to a hippocampus lesion.

\section{Case Report}

A 67-year-old woman was admitted to our hospital with an episode of memory loss lasting 2 hours beginning with dizziness. According to the history, the patient could not recall some faces and repeatedly asked "if she was being taken to the doctor". In her medical examination, she was cooperative, and place, time and person orientation were normal. There were no defects in the examination of strength and sense. No pathologic reflex was found and cranial nerve examination was normal. She was on medical treatment for hypertension, hypercholesterolemia,

Address for Correspondence/Yazışma Adresi: Turgay Dölek MD, Mugla Sitki Kocman University, Department of Neurology, Mugla, Turkey Phone: +90252 2141323 E-mail: turgaydolek@gmail.com.tr ORCID: orcid.org/0000-0003-2124-2968

Received/Geliş Tarihi: 16.09.2020 Accepted/Kabul Tarihi: 21.01.2021

${ }^{\circ}$ Copyright 2021 by Turkish Neurological Society

Turkish Journal of Neurology published by Galenos Publishing House. 
hypothyroidism, cardiac dysrhythmia, and anxiety disorder. She was also taking acetylsalicylic acid $100 \mathrm{mg} /$ day. Cranial computed tomography was normal. A hyperintensity showing diffusion restriction in compliance with acute ischemia was observed in the right hippocampus on diffusion-weighted imaging (DWI) with 4-mm slice thickness [Siemens Magnetom Skyra $3 \mathrm{~T}$ magnetic resonance imaging (MRI)], and hypointensity on apparent diffusion coefficient was observed to comply with this finding (Figure 1,2). The patient was hospitalized with the prediagnosis of hippocampal ischemic TGA. Clopidogrel $75 \mathrm{mg} /$ day was added to the treatment. No abnormality was detected in echocardiography except for mild mitral insufficiency. No abnormal finding was observed in hemogram and routine blood tests. Normal sinus rhythm was observed in rhythm Holter monitoring. An electroencephalography examination was reported as normal. In Doppler ultrasonography, $1.4 \mathrm{~mm}$ diffuse intimal thickening was observed in the common carotid artery (CCA), and a fibrocalcific atheromatous plaque of $2 \mathrm{~mm}$ thickness and protruding from left CCA to the internal carotid artery that did not cause significant stenosis was also observed. The direction of flow, flow velocity, and waveform of vertebral arteries were normal. There was no new event in the patient's $3^{\text {rd }}$-month follow-up.

\section{Discussion}

Epileptic amnesia differs from TGA in terms of lasting for a shorter period, having symptoms like automatism, and recurrence of similar symptoms (5). In our case, epileptic amnesia was excluded according to clinical features. In a recent retrospective study, $70.6 \%$ of 390 patients with TGA had hippocampal lesions (6). As in that study, a hippocampal lesion was found on the DWI of our patient. It is necessary to search for ischemic lesion/ hippocampal infarct in patients with TGA. An ischemic lesion may cause TGA and treatment strategies are different in these patients. Patients with TGA should be examined in terms of

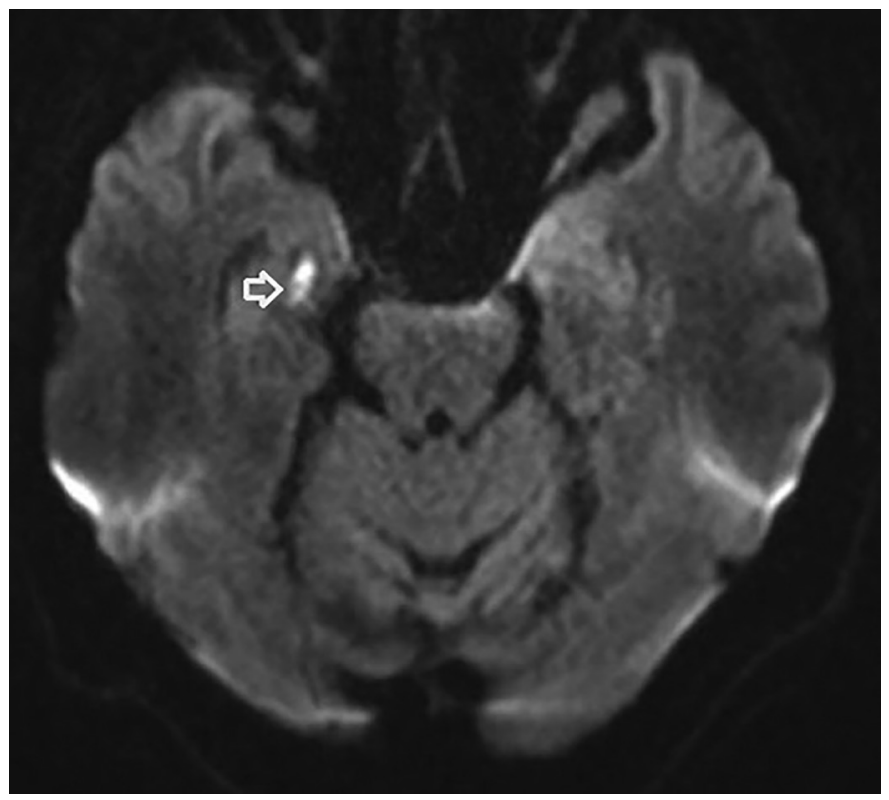

Figure 1. Diffusion-weighted MRI shows diffusion restriction in the right hippocampus region (arrow)

MRI: Magnetic resonance imaging

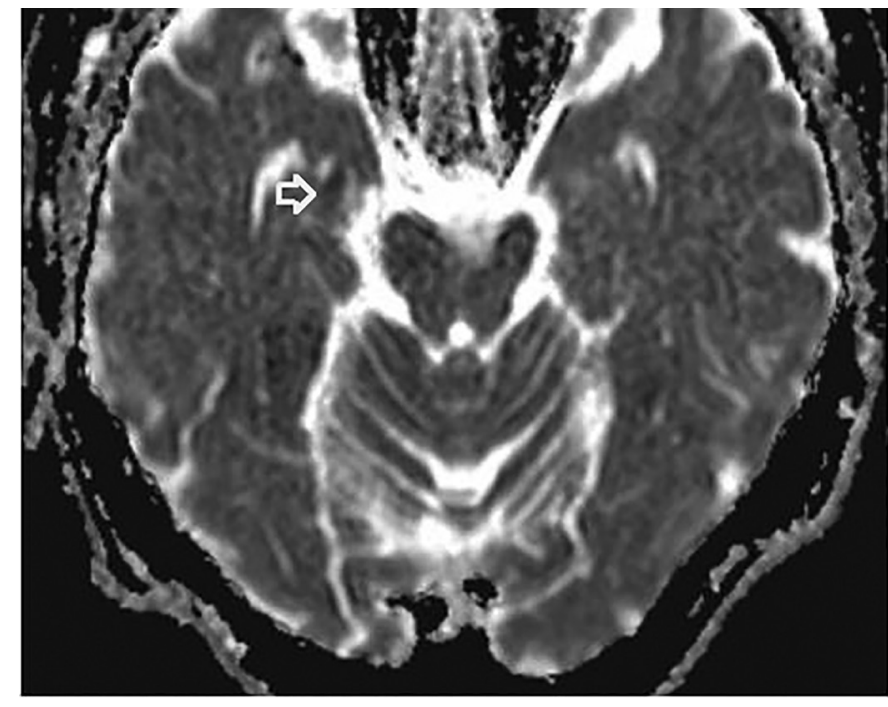

Figure 2. The ADC map shows hypointensity in the right hippocampus region (arrow) consistent with diffusion-weighted MRI hyperintensity in the same area

ADC: Apparent diffusion coefficient, MRI: Magnetic resonance imaging

etiologies such as stroke, epileptic seizure, migraine, and factors including stress, pain, and drugs that may cause amnesia should be evaluated. It should be noted that diffusion-weighted MRI will significantly help in diagnosing the disorder. The hippocampus, fornix, and thalamus should be the regions of interest in radiology. We presented a patient with TGA whose brain MRI demonstrated diffusion restriction in the right hippocampus.

\section{Ethics}

Informed Consent: Informed consent was given.

Peer-review: Externally and internally peer-reviewed.

Authorship Contributions

Concept: T.D., M.K., S.B., G.K., Design: T.D., M.K., S.B., G.K., Data Collection or Processing: T.D., M.K., S.B., G.K., Analysis or Interpretation: T.D., M.K., S.B., G.K., Literature Search: T.D., M.K., S.B., G.K., Writing: T.D., M.K., S.B., G.K.

Conflict of Interest: No conflict of interest was declared by the authors.

Financial Disclosure: The authors declared that this study received no financial support.

\section{References}

1. Enzinger C, Thimary F, Kapeller P, et al. Transient global amnesia: diffusionweighted imaging lesions and cerebrovascular disease. Stroke 2008;39:22192225 .

2. Sander K, Sander D. New insights into transient global amnesia: recent imaging and clinical findings. Lancet Neurol 2005;4:437-444.

3. Sedlaczek O, Hirsch JG, Grips E, et al. Detection of delayed focal MR changes in the lateral hippocampus in transient global amnesia. Neurology 2004;62:2165-2170.

4. Dubois B, Slachevsky A, Litvan I, Pillon B. The FAB: a Frontal Assessment Battery at bedside. Neurology 2000;55:1621-1626.

5. Zeman AZ, Boniface SJ, Hodges JR. Transient epileptic amnesia: a description of the clinical and neuropsychological features in 10 cases and a review of the literature. J Neurol Neurosurg Psychiatry 1998;64:435-443.

6. Szabo K, Hoyer C, Caplan LR, et al. Diffusion-weighted MRI in transient global amnesia and its diagnostic implications. Neurology 2020;95:e206-e212. 